\title{
A new Metapolygnathus platform conodont species and its implications for Upper Carnian global correlations
}

Michele Mazza, Manuel Rigo, and Alda Nicora

Acta Palaeontologica Polonica 56 (1), 2011: 121-131 doi: http://dx.doi.org/10.4202/app.2009.1104

A rich conodont fauna from two Neotethyan sections, Pizzo Mondello (western Sicily, Italy) and Pignola 2 sections (southern Apennines, Italy) includes conodonts described herein as a new species. Metapolygnathus praecommunisti sp. nov. is transitional between Paragondolella noah and Metapolygnathus communisti. The genus Metapolygnathus (including M. praecommunisti) is now characterised by posterior prolongation of the keel termination, associated with a centrally located pit and with a weak ornamentation confined to the anterior part of the platform margins. The establishment of $M$. praecommunisti addresses the problems related to the origin and the peculiar, probably facies-controlled, distribution of its descendant species $M$. communisti. Since $M$. praecommunisti occurs in the entire Tethys and in North America, we propose the species as a good guide fossil for global correlations, characterised by a short temporal range limited to the uppermost Tuvalian (upper Carnian). The stratigraphic occurrence of the genus Metapolygnathus is restricted to the Tuvalian-Lacian (upper Carnian-lower Norian), excluding its presence in the Julian substage (lower Carnian).

Key words: Conodonta, Metapolygnathus, phylogeny, Carnian, Late Triassic.

Michele Mazza [michele.mazza@unimi.it] and Alda Nicora [alda.nicora@unimi.it ], Dipartimento di Scienze della Terra “Ardito Desio”, Università degli Studi di Milano, Via Mangiagalli 34, I-20133 Milano, Italy; Manuel Rigo [manuel.rigo@unipd.it], Department of Geosciences, University of Padova, Via Giotto 1, 35137 Padova, Italy.

This is an open-access article distributed under the terms of the Creative Commons Attribution License (for details please see creativecommons.org), which permits unrestricted use, distribution, and reproduction in any medium, provided the original author and source are credited. 
Fof Full text $(617.2 \mathrm{kB})$ 